\title{
Cost Analysis of Delivery Adult Medication Therapy Services at Ministry of Health in Saudi Arabia
}

\author{
Yousef Ahmed Alomi* iD, The former \\ General Manager of General Administra- \\ tion of Pharmaceutical Care, The former \\ Head, National Clinical Pharmacy and \\ Pharmacy Practice. The former Head, \\ Pharmacy R\&D Administration, Ministry of \\ Health, Riyadh, SAUDI ARABIA. \\ Malika Alhadab, Head, Pharmacy \\ Services, Alyamma Hospital, Ministry of \\ Health, Riyadh, SAUDI ARABIA. \\ Tahani Alotaibi, Supervisor, Inpatient \\ Pharmacy, Pharmacy Services, Alyamma \\ Hospital, Ministry of Health, Riyadh, \\ SAUDI ARABIA.
}

\section{Correspondence:}

Dr. Yousef Ahmed Alomi, The Past

General Manager of General Administration of Pharmaceutical Care, Head, National Clinical Pharmacy and Pharmacy Practice, Head, Pharmacy R\&D Administration, Ministry of Health, Riyadh-11392, Riyadh, SAUDI ARABIA.

Phone no: +966 504417712 E-mail:yalomi@gmail.com

Received: 5-11-2018

Approved: 4-3-2019

Copyright: ๑ the author(s),publisher and licensee Pharmacology, Toxicology and Biomedical Reports. This is an open-access article distributed under the terms of the Creative Commons Attribution NonCommercial License, which permits unrestricted non-commercial use, distribution, and reproduction in any medium, provided the original work is properly cited.

This is an open access article distributed under the terms of the Creative Commons Attribution-NonCommercial-ShareAlike 4.0 License

Access this article online

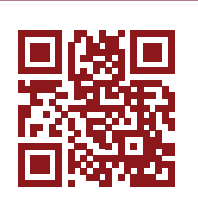

www.ptbreports.org

DOI: 10.5530/PTB.2019.5.28

\begin{abstract}
Objectives: The aim of this study is to explore the cost analysis of drug delivery therapy services for adults' population at Ministry of Health in Saudi Arabia by using American Model with local cost. Methods: It is a cross-sectional 6-months analysis of drug distribution services for adult patients conducted in 2016. It was at 300-bed maternity and pediatrics hospital in Riyadh, Saudi Arabia. The cost calculated adults drug therapy management services delivered to 144 beds. The physician prescribed the medications. The pharmacist reviewed and prepared drugs and distributed through the unit dose system, floor stock distribution and discharge medication services. The fast-moving oral and topical medications were included in the study. The cost model was calculated based on variable expenses including personal cost, material and supply cost. The fixed cost was including direct cost, non-salary cost and overhead cost. All cost was used of US dollar currency and local prices. Results: The estimated cost of drug delivery therapy services for all total number adults' beds per day was $(1,191.965$ USD). It contained three types; the unit dose system (761.35 USD), drug floor stock distribution system (334.99 USD) and discharge medication system (95.62 USD). The cost of delivery of medicines to single bed per day was (13.99 USD) with the highest estimated cost of delivery from discharge medication (6.37 USD), followed by unit dose services (5.29 USD) and floor stock therapy (2.33 USD). The total estimated annual expenditures of drug distribution services were $(435,067.15$ USD). Conclusion: In this adults medication therapy services cost-estimation the first study was conducted at $\mathrm{MOH}$ in Saudi Arabia. It is an essential necessary element of the Pharmacoeconomic program and implements Saudi's future vision 2030 for drug therapy health care services.
\end{abstract}

Key words: Cost, Delivery, Distrubution, Adult, Medication, Therapy, Services, Ministry of Health, Saudi Arabia.

\section{INTRODUCTION}

The processes of medication management consisted of steps including procurement, prescribing, preparation, distribution or dispensing and monitoring. ${ }^{1,2}$ Medication dispensing or distribution involves several types or locations. The dispensing step could be through outpatient pharmacy and inpatient services. There are several types of drug distribution at inpatient pharmacy; drug distribution to discharge patients, drug distribution through unit dose system and drug distribution through the floor stock system. ${ }^{3}$ Most of Ministry of Health hospital pharmacies implemented drug distribution system with specifications of national and international accreditation standards. ${ }^{1-4}$ The general administration of pharmaceutical care at the Ministry of Health released the updated pharmacy strategic plan with new Saudi vision $2030 .^{5}$ That is including many programs and services, including Pharmacoeconomic services. As part of the Pharmacoeconomic, the cost analysis of the Pharmacy services to calculate the economic income and set up the pricing system of healthcare services with health insurance companies. ${ }^{5}$ Several studies published locally for cost analysis of total parental nutrition, drug information services and clinical pharmacy activities. ${ }^{6-9}$ One of the significant things that need to be calculated for the cost is the drug distribution system. Seldom, investigations discussed the cost analysis of drug distribution services for adults patients. ${ }^{10-13}$ The authors based on their best knowledge they are not familiar with any publications done in the Kingdom of Saudi Arabia or Gulf and Middle East countries. The aim of this study is to explore the cost analysis of drug distribution services for adults in Saudi Arabia.

\section{METHODS}

It is cross-sectional 6-months 2016 analysis of drug distribution services for adult patients. It was at 300-Bed Maternity and Pediatrics Hospital in Riyadh, Saudi Arabia. The cost analysis consisted of three domains. Domain 1 was the cost of delivery of Adults drug therapy management with 144 beds. Domain 2 the cost of delivery of pediatrics drug treatment services with 55 beds. Domain three; the cost of delivery for neonatal therapy services with 82 beds. The study was conducted at pediatrics and maternity hospital ambulatory care patient. The hospital had 2801 bed capacity and consisted of maternity and operation related pediatrics section. It had a different type of pediatrics specialties for instant pediatrics endocrinology, pediatric neurology, pediatric infectious disease. The hospital had neonatal critical care and critical maternity sections. The pharmacy distributed the medication through a unit dose system that responded to electronic prescriptions. The pharmacy had 
provided the services $24 \times 7$ to hospital sections. The pharmacy had inpatient and outpatient pharmacy, big extemporaneous preparation section and active medications safety officer. The pharmacy had a drug information center and patient education clinic as part initial clinical pharmacy services at the hospital. For each domain, the physician prescribed the medications. The pharmacist reviewed and prepared drugs and distributed through the unit dose system, floor stock distribution and discharge medications. The nurse administers drugs and follows up by doctors. The drugs were prepared through American Society of Health-System Pharmacist (ASHP) standards and facilities. The oral and topical ready to deliver drugs included in the study while sterile product and compounding formulation excluded from the study. The cost drives from Ministry of Health information database. The cost model was calculated based on variable expenses including personal cost, material and supply cost. Fixed cost was including direct cost, non-salary cost and overhead cost. ${ }^{10}$ All price used US dollar currency and local prices. This study analyses domain one of the cost of delivery of Adults drug therapy management.

\section{RESULTS}

The estimated daily cost of adult's unit dose drug distribution system for all total adults 144 beds was (761.35 US) and (5.29 USD) per bed. The estimated daily cost of adult's floor stock drug distribution system for all total adults 144 beds was (339.32 US) and (2.35 USD) per bed (Table 1). The majority of cost came from overhead cost (55.29\%) and personal cost $(24.61 \%)$ (Table 2 ). The estimated daily cost of adult's discharge medication services for all total adults 15 adults discharge was (91.3 US) and (6.09 USD) per patient. The majority of cost came from overhead cost (76.20\%) and Non-salary cost (19.55\%) (Table 3). The cost of delivery of medicines to single bed per day was (13.99 USD) with the highest estimated cost of delivery from discharge medication (6.37 USD), followed by unit dose services (5.29 USD) and floor stock therapy (2.33 USD). The total estimated annual expenditures of drug distribution services were (435,067.15 USD). The highest budget expenditures from unit dose services $63.87 \%$ (277,892.8 USD), followed by floor stock medication delivery $28.1 \%(122,270.62$ USD) and discharge drug therapy 8\% (34.903.73 USD) (Table 4).

\section{DISCUSSION}

The drug distribution system with three types during discharge or unit dose system and floor stock management at Ministry of Health hospitals

Table 1: Cost analysis of adult's unit dose drug distribution system.

\begin{tabular}{|c|c|c|c|c|}
\hline & Type of Cost & Content of Items & $\begin{array}{l}\text { unit dose } \\
\text { system } \\
\text { Cost (USD) }\end{array}$ & Percent \\
\hline 1 & Personal cost & $\begin{array}{l}\text { Salaries of Physicians, } \\
\text { pharmacist and nurses }\end{array}$ & 505.55 & $66.40 \%$ \\
\hline 2 & $\begin{array}{l}\text { Over Head } \\
\text { cost }\end{array}$ & $\begin{array}{l}\text { Rent, Bed, Computer, Zebra } \\
\text { label printer (Direct Thermal), } \\
\text { Equipment: Refrigerator } \\
\text { Medication trolley, shelves, } \\
\text { creaser and Chairs }\end{array}$ & 187.6 & $24.64 \%$ \\
\hline 3 & $\begin{array}{l}\text { Material and } \\
\text { Supply cost }\end{array}$ & $\begin{array}{l}\text { The average cost of empty } \\
\text { ziplock bag small and big. }\end{array}$ & 5.72 & $9.15 \%$ \\
\hline \multirow[t]{2}{*}{4} & $\begin{array}{l}\text { Non-Salary } \\
\text { cost }\end{array}$ & $\begin{array}{c}\text { Education and Training } \\
\text { Inpatient pharmacy resources }\end{array}$ & 62.48 & $8.21 \%$ \\
\hline & $\begin{array}{l}\text { Total cost } \\
\text { (USD) }\end{array}$ & & 761.35 & \\
\hline
\end{tabular}

Table 2: Cost analysis of adults' floor stock drug distribution system.

\begin{tabular}{|c|c|c|c|c|}
\hline & Type of Cost & Content of Items & $\begin{array}{l}\text { floor stock } \\
\text { drug } \\
\text { distribution } \\
\text { system } \\
\text { Cost (USD) }\end{array}$ & Percent \\
\hline 1 & Personal cost & $\begin{array}{l}\text { Salaries of Physicians, } \\
\text { pharmacist and nurses }\end{array}$ & 83.52 & $24.61 \%$ \\
\hline 2 & $\begin{array}{l}\text { Over Head } \\
\text { cost }\end{array}$ & $\begin{array}{l}\text { Rent, Bed, Computer, Zebra } \\
\text { label printer (Direct Thermal), } \\
\text { Equipment: Refrigerator } \\
\text { Medication trolley, shelves, } \\
\text { creaser and Chairs }\end{array}$ & 187.60 & $55.29 \%$ \\
\hline 3 & $\begin{array}{l}\text { Material and } \\
\text { Supply cost }\end{array}$ & $\begin{array}{l}\text { The average cost of empty } \\
\text { ziplock bag small and big. }\end{array}$ & 5.72 & $9.15 \%$ \\
\hline \multirow[t]{2}{*}{4} & $\begin{array}{l}\text { Non-Salary } \\
\text { cost }\end{array}$ & $\begin{array}{c}\text { Education and Training } \\
\text { Inpatient pharmacy resources }\end{array}$ & 62.48 & $18.41 \%$ \\
\hline & $\begin{array}{l}\text { Total cost } \\
\text { (USD) }\end{array}$ & & 339.32 & \\
\hline
\end{tabular}

\begin{tabular}{|c|c|c|c|c|}
\hline & Type of Cost & Content of Items & $\begin{array}{l}\text { Adults } \\
\text { Discharge } \\
\text { Medication } \\
\text { services } \\
\text { Cost (USD) }\end{array}$ & Percent \\
\hline 1 & Personal cost & $\begin{array}{l}\text { Salaries of Physicians, } \\
\text { pharmacist and nurses }\end{array}$ & 2.49 & $2.73 \%$ \\
\hline 2 & $\begin{array}{l}\text { Over Head } \\
\text { cost }\end{array}$ & $\begin{array}{l}\text { Rent, Bed, Computer, Zebra } \\
\text { label printer (Direct Thermal), } \\
\text { Equipment: Refrigerator } \\
\text { Medication trolley, shelves, } \\
\text { creaser and Chairs }\end{array}$ & 69.57 & $76.20 \%$ \\
\hline 3 & $\begin{array}{l}\text { Material and } \\
\text { Supply cost }\end{array}$ & $\begin{array}{l}\text { The average cost of empty } \\
\text { ziplock bag small and big. }\end{array}$ & 1.39 & $7.79 \%$ \\
\hline \multirow[t]{2}{*}{4} & $\begin{array}{l}\text { Non-Salary } \\
\text { cost }\end{array}$ & $\begin{array}{c}\text { Education and Training } \\
\text { Inpatient pharmacy resources }\end{array}$ & 17.85 & $19.55 \%$ \\
\hline & $\begin{array}{l}\text { Total cost } \\
\text { (USD) }\end{array}$ & & 91.3 & \\
\hline
\end{tabular}

Table 4: Cost analysis of comparisons of all types of Adults Medication distribution services.

\begin{tabular}{|c|l|c|c|c|c|}
\hline No & $\begin{array}{l}\text { Method of drug } \\
\text { delivery system }\end{array}$ & $\begin{array}{c}\text { Cost per } \\
\text { day }\end{array}$ & $\begin{array}{c}\text { Cost per bed } \\
\text { per day }\end{array}$ & $\begin{array}{c}\text { Total cost } \\
\text { per bed } \\
\text { annually }\end{array}$ & $\begin{array}{c}\text { Cost } \\
\text { percent }\end{array}$ \\
\hline 1 & $\begin{array}{l}\text { Unit dose drug } \\
\text { distribution system } \\
\text { Cost (USD) }\end{array}$ & 761.35 & 5.29 & $277,892.80$ & $63.87 \%$ \\
\hline 2 & $\begin{array}{l}\text { Discharge } \\
\text { Medication services } \\
\text { Cost (USD) }\end{array}$ & 91.30 & 6.09 & $33,324.50$ & $7.66 \%$ \\
\hline 3 & $\begin{array}{l}\text { Drug floor stock } \\
\text { distribution system } \\
\text { Cost (USD) }\end{array}$ & 339.32 & 2.36 & $123,851.80$ & $28.47 \%$ \\
\hline & Total Cost (USD) & 1191.97 & 13.73 & $435,069.10$ & \\
\hline
\end{tabular}


in the late 1980s while non-MOH Governmental hospitals in early 1980s. ${ }^{4,14}$ All of the healthcare institutions implemented drug distribution services based on the American Society of Health-System Pharmacist., ${ }^{3,15}$ Currently, they followed medications and management chapter of Saudi Center of Healthcare Accreditation (CBAHI). ${ }^{1}$ Several studies are done about the drug distribution system in Saudi Arabia with recent investigations on Ministry of health hospitals. The new Pharmacy strategic plan recommended implementing the Pharmacoeconomic with cost analysis will all pharmacy services, including drug distribution system. ${ }^{5}$ In the current study, with target aim of a cost analysis of adult's drug distribution system showed all unit dose drug distribution system was considered a high cost. The majority of the cost came from the personal cost similar to the previous study ${ }^{10}$ and that's related to unit dose preparation by pharmacy technicians or pharmacist and needed more staff because they were using standard unit dose procedures, not an automated system. Besides, the second most cost came from the overhead cost that is related to using equipment and trolley of unit dose system with all types of equipment that's needed for preparations. The cost of floor stock distribution system lower cost than the unit dose system. That has excepted because it does need more personal for preparations and pieces of equipment. As a result, the majority of the cost came from overhead cost. The least cost drug distribution system was medications for discharged patients. There is not much personal and small number of types of equipment for medications storage. The hospital may not implement patients counseling program and the pharmacist did not spend much time during discharge dispensing. As results, the personal cost was not considered the second one. The education and training of pharmacist were the other cost came from total discharge drug distribution services. The majority of cost per patient came from discharge patients that's related to the number of discharge patients few as comparisons of the total number of beds. It was representative almost $10 \%$ of beds discharge daily. The unit dose cost considered as the other cost per patient because much served by personal and equipment. While the floor stock system does not need much personal or equipment, which makes it the lowest cost, the findings the majority of the total annual budget came from unit dose drug distribution services that are excepted because of the high number of beds and medications. The second cost from the budget was floor stock distribution services that the related number of medications served for the patient was high. Besides, the equipment not used much and personnel provide services to the patients. While the discharge patient cost was the lowest cost per patient similar to the previous study ${ }^{11,13}$ and higher than other study due different site setting ${ }^{11}$ and that's related to a few patients discharge and without much personal efforts and equipment. This is the first study done in Saudi Arabia to calculate the cost analysis of three types of drug distribution system at the Ministry of Health hospital. Periodically, the cost estimates of drug distribution services, especially with automated drug distribution system is highly recommended at the Ministry of Health institutions in the Kingdom of Saudi Arabia. ${ }^{4}$

\section{CONCLUSION}

In this adult's medication therapy services cost-estimation the first study was conducted at $\mathrm{MOH}$ in Saudi Arabia. It is an essential necessary element of the Pharmacoeconomic program and implements Saudi's future vision 2030 for drug therapy health care services.

\section{ACKNOWLEDGMENT}

None.

\section{CONFLICT OF INTEREST}

The authors declare that there are no conflicts of interest.

\section{ABBREVIATIONS}

MOH: Ministry of Health; KSA: Kingdom of Saudi Arabia; USD: United State Dollars; ASHP: American Society of Health-System Pharmacist; CBAHI: Saudi Center of Healthcare Accreditation.

\section{ORCID ID}

Yousef Ahmed Alomi (D) https://orcid.org/0000-0003-1381-628X

\section{REFERENCES}

1. CIBAHI. Medication Management. In: National Accreditation Standred. $2^{\text {nd }}$ Ed. Saudi Central Board for Accreditation of Healthcare Institutions. 2016. Available from: http://insights.ovid.com/crossref?an=01222928-201713010-00016.

2. The Joint Commission. 2016 Comprehensive Accreditation Manuals. Joint Commission Resources. 2016.

3. American Society of Hospital Pharmacists. ASHP Technical Assistance Bulletin on Hospital Drug Distribution and Control. Am J Hosp Pharm. 1980;37(8):1097-103.

4. Ahmed AY, Jamaan AS, Abdullah AR, Shorog E, Alshahran A, Alasmary S, et al. National survey of pharmacy practice at MOH Hospitals in Saudi Arabia 20162017: Prescribing and medication management. J Pharm Pract Community Med. 2018;4(1s):s54-9.

5. Alomi YA, Alghamdi SJ, Alattyh RA, Elshenawy RA. The evaluation of pharmacy strategic plan in past 2013-2016 and forecasting of new vision 2030 at ministry of health in Saudi Arabia. J Pharm Pract Community Med. 2018;4(2):93-101.

6. Alomi YA, Fallatah AO, Qahtani AAAL, Al-Shubbar N, Al-Yahya MF, Al-Smail EH Cost of total parenteral nutrition services at the ministry of health, Saudi Arabia. Int J Pharm Health Sci. 2019;2(1):39-44.

7. Alomi YA, Al-Jarallah SM. The cost analysis of network drug information services at ministry of health institutions in Saudi Arabia. J Pharm Pract Community Med. 2018;4(4):226-30.

8. Alomi YA, Alsulami N, AlQahtani N, Mashouf M, Qahtani A, Almansor FA. Cost analysis of drug information services at the mental hospital in Saudi Arabia. $J$ Pharm Pract Community Med. 2018;4(2):83-6.

9. Alomi YA, Aldosary BA. Cost analysis of activities for network drug information centers at the ministry of health hospitals in Saudi Arabia. Int J Pharm Heal Sci. 2019;2(1):45-51.

10. Rupp MT. Analyzing the costs to deliver services. Pharm Today. 2011;17:56-64.

11. Gregório J, Russo G, Lapão LV. Pharmaceutical services cost analysis using time-driven activity-based costing: A contribution to improve community pharmacies' management. Res Soc Adm Pharm. 2016;12(3):475-85.

12. Carroll NV, Brusilovsky I, York B, Oscar R. Comparison of costs of community and mail service pharmacy. J Am Pharm Assoc. 2005;45(3):336-43.

13. Middleton TM, Currie DC, Middleton C. Maryland Department of Health and Mental Hygiene. Pharmacy Dispensing Cost Analysis for the State of Maryland. $2011 ; 1-5$.

14. Alomi YA. National pharmacy practice programs at ministry of health in Saudi Arabia. J Pharm Pharm Scien. 2015;1(2):17-8.

15. American Society of Hospital Pharmacists. ASHP statement on unit dose drug distribution. Am J Hosp Pharm. 1989;46(11):2346. 